\title{
THE HUSBAND POSITION IN BAJAPUIK MARRIAGE DYNAMICS IN PARIAMAN
}

\author{
Restia Gustiana \\ Prodi Syariah Sekolah Pascasariana UIN Syarif Hidayatullah Jakarta \\ Jl. Kertamukti No. 5, Pisangan Barat, CiputatTimur, Cireundeu, Kec. Ciputat \\ Tim., Kota Tangerang Selatan, Banten 15419. \\ Email: restia.gustiana15@mhs.uinjkt.ac.id
}

\begin{abstract}
This research conducted to see the position of the husband in a traditional Pariaman marriage known as a Bajapuik marriage. Pariaman is a part of the Minangkabau region, which had opted for the matrilineal system, which affects customary marriages, namely, after marriage, some rights and obligations of the husband are more controlled by the mamak (chiefs who come from the wife's family). This study uses qualitative research in a field research system (Field Research) with an anthropological (ethnographic) approach. The subject of this study leads to key informants that researcher chooser and only (random) based on specific criteria and categories that can describe condition subjectively in the field. The findings of this study indicate that Bajapuik marriage affects the position of the husband in the family. The husband's position in family decisions only an input because the husband is considered a newcomer. The findings of this study reinforce the opinion of Poloma, an action someone will get social sanctions that is along with the times the husband's position began to shift as well as mamak. Mamak is no longer able to carry out her role all rights and obligations are handed over to her husband as well as her husband, who had previously had no burden in providing for his wife and children, bécame an obligation.
\end{abstract}

Keywords: Marriage; Pariaman; Bajapuik

How to Cite: Gustiana, R. (2020). The Husband Position in Bajapuik Marriage Dynamics in Pariaman. Jurnal Ilmiah Al-Syir'ah, 18(1), 13-27.

Permalink/DOI: http://dx.doi.org/10.30984/jis.v18i1.953

Copyright (C) 2020, Jurnal Ilmiah Al-Syir'ah

The Husband Position in Bajapuik Marriage Dynamics in Pariaman 


\section{INTRODUCTION}

Speaking of marriage in Indonesia will not be separated from a variety of unique rituals and customary law in each of their respective regions, and customary law itself in many areas influenced by Islamic law. Consequently, aspects of customary law partly submerged in the shadow of Islamic law, and some are more prominent than Islamic law (Bemmelen \& Grijns, 2018). This diversity caused by differences in the composition of the community in each region (Bakar, 2013). Besides marriage in adat is an essential event in the lives of indigenous peoples, because marriage is not only related to civil relations but also involves the relationship of customs (Hadikusuma, 2007). Their relationship after becoming husband and wife is not just an agreement or contract but a community or organization.

In Minangkabau as a matrilineal society, marriages aim to maintain the maternal lineage. Hence, daughters have to carry out forms of marriage taking husband (sumando/ semenda), which is known as Bajapuik marriage. As a result of this Bajapuik marriage, the husband joins in his wife's family environment and relinquishes his traditional position in the arrangement of his parents' kinship (Yakub, 1995). In the Minangkabau community, especially in the Pariaman area, Bajapuik is a tradition that cannot be left behind in the marriage rituals in Pariaman. If the Bajapuikceremony not found in the marriage process, it will become a conversation by the surrounding community and dubbed as a person who has no civilization. Therefore:

"Pemberian uang japuik harus ada, apapun caranya, misal pihak perempuan tidak sanggup, maka pihak laki-laki boleh untuk memberikan bantuan. Bantuan ini, disembunyikan dari masyarakat hanya pihak keluarga saja yang tahu, keadaan seperti bukan suatu masalah yang penting adat terlaksana."

"Provision of Jaipuk money must be there, whatever the means, for example, the woman is unable, then the man may be able to assist. This assistance, hidden from the community, is only known by the family, such conditions are not an important issue which is customary" (Interview, Afdal Community Figure (Adat), November 13, 2017).

The statement above shows the firmness of the Pariaman Customs in establishing Bajapuik marriage rules. Bajapuik marriage is a marriage that is required to give a certain amount of money, gold, and other objects of value to the man known as Jaipuk money. The giving of Japuik money carried out when the marriage contract will take place where the female party picks up the bridegroom to carry out the marriage contract by bringing a sum of money, gold, and other items that have determined at the time of marriage (Mutia, 2000). 


\section{Jurnal Ilmiah Al-Syir'ah Vol. 2018, No. 1 (2020): 13-27 \\ Website: http://journal.iain-manado.ac.id/index.php/JIS ISSN 2528-0368 (online) ISSN 1693-4202 (print)}

Pariaman custom is one of Indonesia's cultural diversity that has a unique tradition in the procession of traditional marriages. It not usually heard in general that women give something to men when they are going to get married; on the contrary, men give something to women who often referred to as delivery. This situation is because Pariaman is part of the Minangkabau, who adheres to the matrilineal system and adat after marriage is matrilineal (living around the relatives of his mother) (Anwar, 1997). As a result, a husband will become a Sumando (immigrant person) in his wife's house. According to some views in the community, it is appropriate if a prospective husband gets a lot of money from his wife before they get married. However, at the welcome of the woman in the house of the man, the man will return the money in the form of goods which are usually worth more than the cash given (Maihasni, 2010).

The writer's opinion on the Bajapuik marriage shows that women have more roles than men in the practice of marriage in Pariaman. As reviewed in previous research inAsmaniar, (2018), in her study entitled "Minangkabau Indigenous Marriage."Said that the Minangkabau indigenous peoples' marriage had 2 (two) forms, namely: (1) Ideal marriage, namely marriage between close family such as children of nieces; (2) Abstinence, that is a marriage that cannot carry out like a mother or father's child. There are two procedures for the marriage of the Minangkabau indigenous people, namely: 1) Marriage according to female relatives, namely the woman who is the initiator in marriage and domestic life, from starting to find a mate to the marriage. 2) Marriage, according to male relatives, namely the men who are the initiators of marriage and households, from finding a mate to the marriage and the cost of daily living. This study reinforces the study of the writers which this study addresses Minangkabau traditional marriages in general, while the writers proceed specifically. Therefore the writer is interested in further studying how the husband's position in this Bajapuik marriage.

\section{RESEARCH METHODS}

This research was conducted from November 2017 to February 2018, in the district of Padang Pariaman, Sungai Limau District, specifically Pilubang Kenagarian. The writer researched Nagari Pilubang because the writer found the practice of Bajapuik marriage in the area on January 4, 2018. This research is qualitative research with field research that uses a legal anthropological approach (cultural ethnography), which is an approach used to find out and examine local legal realities (Soeroso, 2011). In this case, the writer examines the position of the husband in a traditional Pariaman marriage.

In addition to ethnography, as stated above, this research also uses a case study approach, which is a study conducted on a unified system. This unity can be in the form of programs, activities, events, or groups of individuals who are bound by a particular place, time, or bond. So in this study, the writers tried to examine the cultural factors that make the Bajapuik marriage still exist until now. In this study, the writer directly interacts with the local community so that all problems 


\section{Jurnal Ilmiah Al-Syir'ah Vol. 18, No. 1 (2020): 13-27 \\ Website: http://journal.iain-manado.ac.id/index.php/JIS \\ ISSN 2528-0368 (online) ISSN 1693-4202 (print)}

related to adat marriage can be known, understood by the writer clearly (Rahardjo, 2017).

The subject of this research is more towards key informants selected based on specific criteria and categories that can describe conditions objectively in the field. The dimensions of age, social status, and role as well as with other social groups related to the problem studied and the social reality of the Pariaman community that is still strong in their traditional traditions. So this study is more focused on conventional leaders, Alim Ulama, and some other strata of society. The writer also conducted observations and interviews with the community who carried out the tradition of Jaipuk money and Ilang money in carrying out this tradition, so that this research was objective. Determination of data sources finished by a random technique, which is a technique that is used randomly from one informant to another informant so that all places represented to provide information to the writer. Besides, the writer also traced data to historical sites and Customary institutions to support the disclosure of facts and the background of the Bajapuik marriage.

The researcher obtained several data sources to answer the questions of the writer's researchers, consisting of (a) The community, those who always support the practice of my informant's Bajapuik marriage, namely: Basril, Darlini, Manidar, As, Astri, and Yos; (b) AlimUlama, CadiakPandai and NiniakMamak people who wrote the Bajapuik marriage always to carried out my informants, namely: Juridical, Afdal, and Rosman; (c) WaliNagari, namely the regional leader or equivalent to the RT who legalized the Bajapuik marriage.

These three sources are the informants who answer the researcher's research questions. Researchers conducted interviews with Forum Group Discussions (FGD), where researchers gathered informants at one time and one place. Besides, researchers also extract information from individual informants directly.

\section{RESULTS AND DISCUSSION}

After the writer reviewed and discussed the Bajapuik marriage in Pariaman, the writer found that the practice of Bajapuik marriage already embedded in the Pariaman community. The Pariaman community has meanings and values in the preparation of Bajapuik marriage so that the tradition of Bajapuik marriage has survived until now. However, the sense and values felt by indigenous peoples themselves are experiencing a shift between the past and present communities.

\section{Shifting Meanings and Values in Bajapuik Marriage Practices}

Every community in their lives will experience changes. Changes in this society will occur continuously. However, one community change with another culture is not the same, andsome people experience changes more quickly when compared with other communities (Simanjuntak, 2002). Social change is the hallmark of all societies and all cultures, both traditional and modern societies. But 


\section{Jurnal Ilmiah Al-Syir'ah Vol. 2018, No. 1 (2020): 13-27 \\ Website: http://journal.iain-manado.ac.id/index.php/JIS ISSN 2528-0368 (online) ISSN 1693-4202 (print)}

the difference is that in contemporary society, the change is swift, and in the orthodox community, it is prolonged (William Haviland, 1993).

According to Moore, changes that occur in society involve complex matters. Social change is a change related to social structure. Social structures are patterns of behavior and social interaction. Besides, Moore also includes social change as an expression of fabrics such as norms, values, and cultural phenomena (Laurer, 1989). Soekarno also believes the same thing, that the human environment causes a change, the influence of other cultures, and cultural contacts (Soekanto, 1990).

According to Sastramiharja, social change is a significant change of social structure, including patterns of social action and interaction as a result and manifestations of structures that contain norms, values, cultural products, and various symbols. Besides, social change also involves multiple levels of social life, ranging from the smaller to the larger. However, William A. Haviland argues; differently, social change occurs because of discoveries, diffusion, loss of culture, and acculturation (William Haviland, 1993). According to Simanjuntak, adat in social change cannot stand alone. Both influence each other. The difference is a process that can measure through a scale back and forth, up and down, a lot or a little, integrated, or disintegration (Simanjuntak, 2002).

According to Adiwikarta, social change can be caused by education because education in human life has two essential roles, namely, as the preservation of cultural and social systems (agents of conservation) in addition to being carriers or agents of change (agent of change). The preservation of education culture has bequeathed a system of values, beliefs, knowledge, norms, and customs as well as a variety of traditional behaviors. That has entrenched from one generation to another, while agents of change education construct new forms due to old types that are not suitable again (Adiwikarta, 1988).

Comte, in his thoughts cited by Salim, argues that social change is a social dynamics, Ie seeking to find out the rules of social phenomena in different time frames. Comte argues that to understand the birth period of modernity, we need to place social change in a broader historical context. Besides, social change treated as just one phase of the long journey of human history in cultural development (Salim, 2002).

Social changes that occur along with the development of the understanding of the Zoon Politicon community, which is along with the development of the times the needs of the city with other communities more broadly, marked by economic growth to maintain life. The development of thinking about the importance of the economy affects the marriage tradition; marriage is measured more in terms of material, following the opinion of Karl Marx states that everything is only measurable with equipment and economics (Warrington, 2008). 


\section{Jurnal Ilmiah Al-Syir'ah Vol. 18, No. 1 (2020): 13-27 \\ Website: http://journal.iain-manado.ac.id/index.php/JIS ISSN 2528-0368 (online) ISSN 1693-4202 (print)}

Therefore, there is a shift in meaning and value to the community in giving Jaipuk money and Ilang money as a medium of exchange in the Bajapuik marriage tradition. This switching sees as follows:

\section{It initially titles of nobility (prestige), which became the basis for consideration in giving Jaipuk money and Ilang money}

The background which strengthens the writer is that the giving of Jaipuk money and Ilang money influenced the title of nobility that affixed to the men in PariamanNagari. This title considered to have special features for the Pariaman community and inherited from one generation to the next.

Nobility follows the father's lineage and passes on to his son. The intended titles are sidi, bagindo, and sutan. The title sidi comes from Sayidina, namely Sayidina Muhammad means the prince or religious leader, the title of bagindo comes from the king, the king's apostle saying king or leader and the sutan title comes from the sultan which means the king or leader. The title sutan intended for local kings who have converted to Islam. In history, it said that the title of sutan originated from the title of a king from Aceh, whose influence in developing the religion of Islam in Pariaman.

The writer concludes that the development of Islam strongly influenced these three titles in Minangkabau at that time. People who have an in-depth knowledge of Islam will be the main priority of the community in finding a partner for their children. A noble title carried by someone representing the criteria in finding a partner in adat and Islam that already seen the descendants and religion of someone who will be taught by the son-in-law.

The primary purpose of the title of aristocracy as criteria for finding a partner is to get good offspring. The standards seen from his wealth, which is one of the tools to know the ability of men to support and meet the economic needs of their household, is not a consideration of society. This situation is due to women Minangkabau as a maternal lineage (matrilineal) has possessed inheritance (inheritance), which is inherited down and down, to fulfill daily life (Hamka, 1984).

The criteria for determining a partner with a peerage did not last long. Along with the development of a peerage society, it is not something that becomes the basis of exchange for a Bajapuik marriage again. At present, the consideration in finding a partner is an achievement. According to Weber, in traditional societies, social status is often determined by the knowledge possessed by a person, and that can change according to the development of time (Giddens, 2002). Therefore, initially in the Bajapuik tradition, men who accepted as sons-in-law are those who have aristocratic titles change in the achievements of a person. 
At present, achievement is the basis for consideration in giving Jaipuk money and Ilang money

At this time, in Pariaman village, which is the basis for consideration of a Bajapuik marriage, it is seen from how much income a man will make as a potential son-in-law. Benchmarks determine the size of a person's revenue for the community seen from the education and profession they achieve. As the writer found in the informant Manidar stated in a spirit of ethics (a call for someone who was the same age as a mother), Manidar explained to the writer that:

“...Untuk sekarang ini yang menjadi pertimbangan dalam perkawinan bajapuik masih pada status gelarnya, tapi dari status gelar pendidikan atau pangkat kerjanya bukan lagi gelar kebangsawananya. Itu merupakan sesuatu yang logis saja terjadi dalam masyarakat. Masyarakat tentu akan berfikir dengan apa dia akan hidup, jika hanya mengandalkan gelar keturunan. Dahulu ya, tidak menjadi masalah karena kebutuhan dengan penghasilan masih seimbang, lahan yang akan digarap masih luas dan masih ada mamakyang akan memperhatikan. Tetapi sekarang semuanya itu berubah, kebutuhan ekonomi meningkat, lahan mengecil dan mamak perhatiannya sudah berkurang karena sibuk dengan kebutuhan keluarganya sendiri”".

"... for now, consideration in the Bajapuik marriage is still in the status of his title, but from the status of his education or work rank is no longer his peerage. That is something logical that just happens in society. The public will certainly think with what he will live if only relying on heredity. In the past, it was not a problem because the need for income was still balanced; the land to cultivated was still large, and there were still mamak who would pay attention. But now all that is changing, economic needs are increasing, the land is getting smaller, and mamak has less attention because it is busy with the needs of its own family" (Interview, Manidar as Indigenous Peoples, November 13, 2017).

From these two reasons, according to the writer, the community's consideration in the implementation of the Bajapuik marriage, for now, is not a peerage anymore, but it sees from a man's socioeconomic status (achievement). Achievements achieved through individual endeavors, such as education, employment, and income earned by someone. It affects the giving of Japuik money and lost money in the Bajapuik tradition.

In Pariaman, boys who have achievements will have high bargaining value in the community and vice versa. This situation has become a public conversation of the Pariaman community from the old to the young. These conversations, the writer met when the writer was in public transportation; at that time, the writer wanted to market Pariaman or often called pasapiaman. In addition to the writer's general transit, there were several more people in it consisting of mothers, two schoolchildren, and gentlemen of whom we certainly did not have the same goal,

The Husband Position in Bajapuik Marriage Dynamics in Pariaman 


\section{Jurnal Ilmiah Al-Syir'ah Vol. 18, No. 1 (2020): 13-27 \\ Website: http://journal.iain-manado.ac.id/index.php/JIS ISSN 2528-0368 (online) ISSN 1693-4202 (print)}

and only we were transported to meet because of the same path. The journey progresses; the writer focused on two mothers who sit next to the writer and face each other. The two mothers, engrossed in talking about their children, caught the attention of the writer when one of the two mothers, just call him Tini's mother. The mother told me that her son, who had been studying at Andalas University (UNAND), now it has worked at a company in Jakarta. With enthusiasm, the other mother responded with a few questions, just call her mother Ani, as follows:

“...Ondeeh (pernyataan kagum), Anak uni Tini hebat, ngomong-ngomong anaknya uni Tini, sudah punya calon pasangan belum? Dia kalau menikah pakai uang japuik kah? Kalau pake, pasti uang japuiknnya besar kan?”.

Ms. Tini, responds to Ms. Ani's question by answering:

“...Iya, Alhamdulillah anak saya sukses. Kalau masalah jodoh belum ada, ini saya sedang mencarikan yang cocok, disamping dia mencari sendiri.Terkait pakai atau tidaknya uang japuik tentu harus pakai, karena itu adat kita.Tapi, masalah berapa besar uang japuiknya tergantung dari pihak calon pasangannya.Saya tidak ada mematokan harga dari sekarang”.

Mrs. Tini, returned the response from Mrs. Ani, as follows:

“...Ya betul itu uni, adat kita tidak boleh hilang, sekarang ada yang tidak memakai adat dalam proses perkawinannya, dikarenakan pengaruh luar yaitu kelamaan pergi merantau".

Besides, at different times the writer also found the same perception. At that time, the writer attended the Primary School friends reunion event. After not meeting for a long time with usual conversation, is a discussion about the profession that currently undertaken at the moment. Talks that make the atmosphere crowded are jokes about giving Japuik money. There is one of us who just called his name Rio. He has a higher profession than our other friends, so Rio is the object of their jokes, with a statement from one of our friends calling him Andi, as follows:

"Wuiiih (clicked in admiration), Rio kamu pasti uang japuik-nya mahalkan?Karena jabatan profesi kamu tinggi.Semua Semua yang ada disana ikut menyeru, dengan gelak tawa dan sahutan salah satu dari mereka, ya iyalah, pastinya itu. Rio hanya membalas dengan senyuman".

From the case above, the writer believes the consideration in the Bajapuik marriage is an achievement. Regarding the issue of giving Japuik money, it becomes the liaison between the community. The writers conclude that the higher the work or income of a boy who will match, the higher the bargaining price of his Japuik money. In other words, the higher the socioeconomic status of a man, the higher the amount of Japuik money and Ilang money lost. From the results of the study the writers found, the standard of giving is based on the socioeconomic status of the Pilubangnagari community, Padang Pariaman Regency. See the following figure 1. 


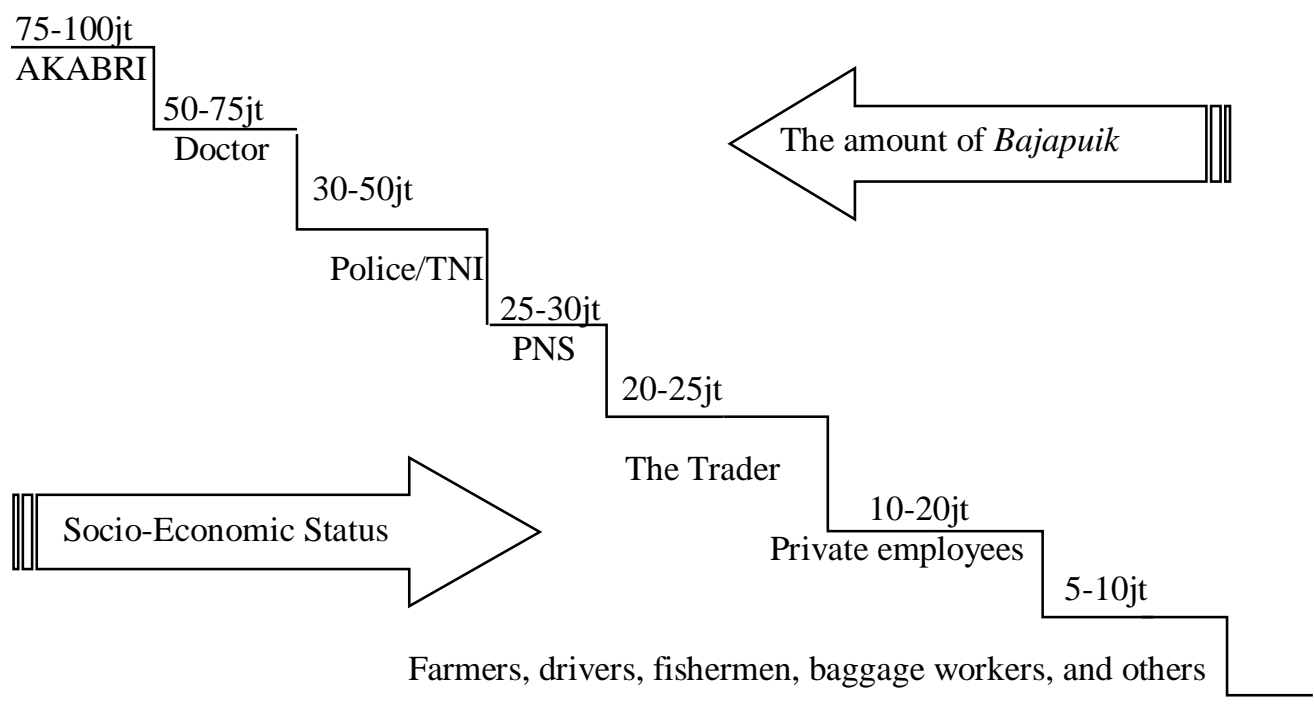

Source: Interview with KAN Members 2017

\section{Figure 1. Japuik Money Based on Socioeconomic Status in Padang Pariaman Regency}

In the figure above, it appears that people have their standards in determining the amount of Japuik money. The rule of giving Japuik money can see from the status of the work owned by a man who will be a son-in-law. The work status of a man in the view of the Pariaman community can move the household life that will live. For the Pariaman Society, at the moment, the consideration in the Bajapuik marriage is the employment status of men who will rob of it. This condition, according to Sumaksari, is in line with the marriage requirements in the Minangkabau custom, namely husband candidate (marapulai) must already have a source of income to be able to guarantee the life of his family (Sukmasari, 1983).

The giving of lousy money in figure 1 ranges from 5 million to 100 million, is not something permanent. Determination of the amount of Japuik money in figure 1 is only as a basis for community consideration in determining the average amount of jawik money based on the socioeconomic status of the community. In reality, the distribution of money is less than 5 million and can exceed 100 million or even without money. The amount of small money given depends on the prestige and capability of the female family. Like the statement as follows:

"...Kami, memberikan uang japuik melihat dari prestasi dari orang yang akan dijemput sebagai calon menantu. Jika yang dijemput punya pendidikan dan pekerjaan yang bagus, maka mamakdari pihak perempuan tidak segan-segan menawarkan uang japuik yang tinggi".

"... We, giving a lot of money, look at the achievements of the people who will pick up as prospective daughters-in-law. If those who picked up have 


\section{Jurnal Ilmiah Al-Syir'ah Vol. 18, No. 1 (2020): 13-27 \\ Website: http://journal.iain-manado.ac.id/index.php/JIS ISSN 2528-0368 (online) ISSN 1693-4202 (print)}

good education and jobs, then women are not reluctant to offer high cash fees. (Interview with Rosman, 2017).

In other cases, in giving Japuik money, the statement of mamak from the women was as follows:

From the statements of the two informants above, the writer understands that giving Japuik money depends on the agreement between the two parties to get married. However, the deal did not just happen, and there were rules of the game that played to reach an agreement. A man getting a bargain price of big money did not mean that his family immediately accepted it. However, the male family will give a higher rate than the price offered by the woman. So, at that time, there was a bargaining game between the men and women (bargaining position). The aim is to show that giving cash is competitive.

The two informants above indirectly showed a shift in meaning in giving Japuik money. Initially giving Japuik money based on heredity, now the consideration in the Bajapuik marriage is an achievement. This shift happens to adjust to the current state of society. In the past, the status of a noble title was a matter of consideration in choosing a son-in-law because he respected the title attached to men in Pariaman. Regarding achievement was not one of the reviews at the time. At that time, the inheritance of inheritance in the form of agricultural land was more than enough to meet family needs. The different cases at this time, declining farming yields that affect income and inheritance of inheritance assets, are running low because traded for development and others. Besides, with the advancement of community education, reducing heirs in managing heirlooms (LKAAM, 1987).

The reduced management of inheritance is due to the community being more interested in migrating (trading) and serving in professions related to government and private institutions (see figure 1) because they have a more promising income. Therefore, for now, the consideration in finding a partner in Pariaman is socioeconomic status. The inclusion of economic values in the marriage process affects the social status of the nationality title in Pariaman. Noble titles are of no importance when they don't provide a bright future. It the opinion supported by Karl Max, stating that economic factors occupy a person in a particular layer (Azwar, 2001).

The inclusion of economic values in the marriage process affects the social status of the nationality title in Pariaman. Noble titles are of no importance when they don't provide a bright future. Its idea supported by the opinion of Karl Max, stating that economic factors occupy someone at a particular layer (Jones, 2010). Likewise, Homans, in his theory of proposition of rationality, states that socioeconomic status, which realized in the form of work and income, is a logical and acceptable society today (Homans, 1961). 
Then, what about the previous peerage? Noble titles remain. At present the knighthood is only a symbol in marriage, as the informant's statement goes as follows:

"Laki-laki di Pariaman, kalau sudah menikah orang memanggilnya tidak dengan pakai nama lagi, tetapi di panggil dengan gelarnya sidi, sutan atau bagindo.Gelar tersebut mengikuti gelar yang diturunkan dari ayahnya. Sebagaimana adat berkata: Lahir diberi nama, besar diberi gelar”.

"Men in Pariaman, when they are married people call him by not using a name anymore but called by his title sidi, sutan or bagindo. The title follows a title handed down from his father. As custom says: Birth given a name, grand given the title ". (Interview with Rosman, 2017)

From the statement above, it said that currently, the national title only used as a symbol, namely as a sign that a married man (husband) is a sumando (immigrant). The wife's family calls a husband with a title handed down by the husband's father. Calling a husband based on this title only applies when a husband is in his wife's environment. When the husband is in his family environment, this title is lost. The husband called by his name, but when the husband appointed as an elder, he is called mamak in his community.

From the initial distribution of Japuik money based on the title of nobility, now shifted based on achievements. It shows that there is a shift in Bajapuik tradition. The shift occurs not instantaneously but takes place in accordance with community development. Comte's theory of evolutionism corroborates this statement. In his view, society develops to perfection through a very slow process known as the theory of evolution (Etzioni, 1973).

So, now it is clear that giving money is based on merit as a social exchange that uses economic transactions. In giving Japuik money by the woman, it is not a gift, but there are benefits found by the woman. The expected advantage is that guaranteed future family life. This situation corroborated by the Blau theory "the emergence principle" (the emergence of a principle) in which people attracted to each other through mutual needs and satisfaction. The assumption is that the person gives the reward, doing it as payment for the value received (Poloma, 2000).

The choice of the community on socioeconomic status, as described above, can be a direct or indirect result of the development of society, especially related to education and the profession. For now, economic factors are a logical thing that happens in the community. So far, giving money is based on merit because it provides great hope to women. This hope guaranteed for their family life going forward. There is a process of giving a lot of money due to the benefits of the actors involved. But sometimes the reality is not always as you wish. According to Homans' terminology, people engage in behavior to get something rewarded or avoid punishment (Homans, 1961). 
Jurnal Ilmiah Al-Syir'ah Vol. 18, No. 1 (2020): 13-27

Website: http://journal.iain-manado.ac.id/index.php/JIS

ISSN 2528-0368 (online) ISSN 1693-4202 (print)

\section{Position of Husband in a Bajapuik Marriage in Pariaman}

\section{The husband lives at the wife's house}

In Minangkabau, a married man lives with his wife's family. After Marapulai was picked up and taken to his wife's home, he has since become a new member of his wife's family. The membership is not full, meaning that the husband cannot become a member of his wife's tribe. Therefore many new husbands are at his wife's house at night. He returned to his wife's home at dusk and returned to his parents' home in the morning. It can say at that time, and a husband only slept in his wife's home until his wife had a child (Personal Interview with Afdal, 2017).

The existence of a child between husband and wife changes the situation. Husbands no longer have to go home to their parents' homes, because they already have children who must defend. In this situation, the husband has begun to settle in his wife's house. They get rice fields or land to work on to support their families. Now the husband must divide his time to do his work and work that is in his wife's home. Besides, the husband also has responsibilities at his mother's house that is responsible for the nephew born to his sister. This situation is known as "the child on the nephew in the guidance" (Personal Interview with Rosman, 2017).

Even though they have received arable land, a husband cannot act alone at his wife's home. Everything that done must tell mamak home. Like, to the fields, planting rice, rice, and harvesting rice. This situation is because, at his wife's house, he is not the head of the house. The head of the house is the mother of the house, just as the husband is at home, his parents are as the mother of the house who will arrange everything needed in the job (Personal Interview with Afdal, 2017).

A man who is married and has children, he must always visit his nephew's house or his parents' house. If no one does that, he will be said to have been pawned because he was blind to his nephew. This will be dangerous for his old age. In his old age, he would not be ignored by his nephew and living in his wife's house. If it hurts, it will not be visited and visited by his nephew. This is a disgrace to you Minang men because traditionally a man who has been married in old age should live in the midst of his nephew and when he dies will be buried in the inheritance of his people (Personal Interview with Rosman, 2017).

However, what about people who migrate. Automatically newly married couples do not live with his wife's family but live alone with the house rented or made themselves. Then, they return to their village will continue to follow applicable customs. A husband will not bring his wife home to his mother's house but to the wife's family's home. If the husband and wife want to make their own house in the village, surely the house will be built within the wife's family. The status of the husband is a migrant (Sumando person), a husband not included in the structural kinship of the wife's tribe. (Personal Interview with Afdal). 
Jurnal Ilmiah Al-Syir'ah Vol. 2018, No. 1 (2020): 13-27

Website: http://journal.iain-manado.ac.id/index.php/JIS

ISSN 2528-0368 (online) ISSN 1693-4202 (print)

\section{Husband Has No Burden in Supporting His Wife and Children}

It has discussed in point 1 that the effect of Bajapuik marriage is one of them; the husband joins his wife. In other words, the husband lives in his wife's family. The responsibility of the husband at his wife's home is limited to his child. Children are the responsibility of a father. The wife is not the husband's responsibility because the wife has an inheritance that managed for her needs. Although responsible for the child, this responsibility is not absolute, besides there is a mother who takes care of her nephew. All liability is with the mother in the house of his wife. Mamak is even responsible for high education in his nephew. Therefore the position of the husband at his wife's home is only as a maid role, and the husband only has a vital role at his parents' house, namely as mamak. This husband's position is closely related to his status as a guest, immigrant, or called urangsumando. So the husband is not in control, because there is no control, the sister of the woman who took over.

This role has changed, such as from the second cause of the Bajapuik marriage, the factor of increased economic needs, and diminished land. The part of the mamak has fallen dramatically, not having a significant role anymore on his younger siblings and nephews. Mamak only has the following purposes: (1) Permitting his nephew to be married, namely the presence of mamak's signature in a marriage certificate or can also be referred to as a witness; (2) Giving a title to the nephews of men who are going to get married, sidi, bagindo or sutan, each of which is inherited; (3) Mamak also helps in resolving disputes that occur between his conflicts, such as disputes related to inheritance.

Three roles above all the functions handed over to the husband; this becomes a dilemma in the Pariaman community. The husband is not ready to take on this role because the husband is experiencing a decline in the part of mamak, plus the husband feels that the wife still has a treasure that again meets her needs.

\section{CONCLUSION}

In the results and discussion that the writer studies about the husband's position in the dynamics of the Bajapuik marriage in Pariaman, it can be concluded that the husband's status as a migrant (sumando) in the wife's family. This situation means that the husband is not in the structural family of the wife, the husband's position as a subordinate in other words, the husband cannot directly command his family. The leader in the family is mamak. But with the development of the era, the position of this mamak began to shift. The area of the husband also changed, which was the husband did not have the burden of supporting his wife and children, it became an obligation for him. On the other hand, the husband on the family's side as a mamak figure had to leave his responsibility as a mamak. Seeing this phenomenon in the Bajapuik marriage, the community indirectly changes the meaning and values in the Bajapuik marriage. At first, the Bajapuik marriage, in the sense of pretense, is now an achievement. In the Pariaman community, the performance is more meaningful and valuable than one's nationality title. Besides,

The Husband Position in Bajapuik Marriage Dynamics in Pariaman 
this achievement gives peace to the women in running their household. However, on the other hand, some people do not use Japuik money, one of which is due to the reduced role of mamak. Therefore the writers conclude, for now, the community in carrying out Bajapuikmarriage divided into two parts. First, people who still feel the meaning and values in the practice of the Bajapuik. Second, the people who make Bajapuik only as a symbol.

\section{ACKNOWLEDGMENT}

The writer, thanks to UIN Syarif Hidayatullah Jakarta graduate school and my thesis supervisor Prof. Dr. Arskal Salim and all parties involved, helped during the research process. The writer also thanks all the editorial teams of the Jurnal Ilmiah Al-Syir'ah who helped publish this article.

\section{REFERENCES}

Adiwikarta, S. (1988). Sosiologi Pendidikan: Issu dan Hipotesis Tentang Hubungan Pendidikan dengan Masyaqrakat.

Anwar, C. (1997). Meninjau Hukum Adat Minangkabau.

Asmaniar. (2018). Perkawinan Adat Minangkabau. Bina Mulia Hukum, 7(2), 131140.

Azwar, W. (2001). Matrilokal dan Status Perempuan dalam Tradisi Bajapuik.

Bakar, L. A. (2013). Revitalisasi Hukum Adat Sebagai Sumber Hukum Dalam Membangun Sistem Hukum Indonesia. Dinamika Hukum, 13(2), 4-14.

Bemmelen, S. T. van, \& Grijns, M. (2018). Relevansi Kajian Hukum Adat: Kasus Perkawinan Anak dari Masa ke Masa. Mimbar Hukum, 30(3), 516-543.

Etzioni, A. (1973). Dimensi Moral Menuju Ilmu Ekonomi Baru. Remaja Rosdakarya.

Giddens, A. (2002). Sociology.

Hadikusuma, H. H. (2007). Hukum Perkawinan Indonesia Menurut Perundangan Hukum Adat Hukum Agama. CV Bandar Maju.

Hamka. (1984). Islam dan Adat Minangkabau.

Homans, G. C. (1961). Social Behaviour As Exchange. American Journal of Sociology, 63(6), 597-606.

Jones, P. (2010). Pengantar Teori-Teori Sosial dari Teori Fungsionalisme Hingga Post-Modern.

Laurer, R. (1989). Prespektif Tentang Perubahan Sosial.

LKAAM, L. K. A. A. M. (1987). Pelajaran Adat Minangkabau: Sejarah dan Budaya. Tropic Offset Printing.

Maihasni. (2010). Eksistensi Tradisi Bajapuik dalam Perkawinan Masyarakat Pariaman Minangkabau Sumatera Barat. 
Mutia, R. (2000). Upacara Adat Perkawinan di Padang Pariaman.

Poloma, M. M. (2000). Sosiologi Kontemporer. Raja Grafindo.

Rahardjo, M. (2017). Studi Kasus dalam Penelitian Kualitatif: Konsep dan Prosedurnya.

Salim, A. (2002). Perubahan Sosial: Sketsa Teori dan Refleksi Metodologi Kasus Indonesia.

Simanjuntak, A. (2002). Konflik Status dan Kekuasaan Orang Batak Toba. Jendela.

Soekanto, S. (1990). Sosiologi: Suatu Pengantar. CV Radjawali.

Soeroso, R. (2011). Pengantar Ilmu Hukum. Sinar Grafika.

Sukmasari, F. (1983). Perkawinan Adat Minangkabau.

Warrington, M. H. (2008). 50 Tokoh Penting dalam Sejarah.

William Haviland. (1993). Pengantar Antropologi Jilid I dan Jilid II.

Yakub, N. (1995). Hukum Kekerabatan Minangkabau. 